\title{
Peningkatan Libido dan Homon Testosteron melalui Suplementasi Herbal pada Sapi Pejantan PO
}

\section{(The Increased libido and Testosterone Homones with Herbal Supplementation in PO Bull)}

\author{
Luthfi M, Firdaus F, Affandhy L \\ Loka Penelitian Sapi Potong, Jl. Pahlawan 02 Grati, Pasuruan \\ luthfi.m888@gmail.com
}

\begin{abstract}
This study was aimed to evaluate the effect of herbal supplementation on increasing libido and the concentration of testosterone in PO bulls. This research was carried out in a experimental cage, Beef Cattle Research Institute for 60 days. The research material consisted of $12 \mathrm{PO}$ bulls, each with four heads with a range of ages of 3 to 5 years. The treatment was done, treatment A (Vitamin A + E + Mineral Zn), B (Vitamin A + E + Mineral Zn + 100 grams of Moringa oleifera), and C (Vitamin A + E + Mineral Zn +50 ) gram Moringa oleifera). Data analyzed using Completely Randomized Design (CRD) with One Way Anova. The results showed that the appearance of PO bulls libido given herbal supplementation showed a lower value, meaning the cow had a faster response in succession to treatment C: 100.23 \pm 160.43 ; A: $153.83 \pm 175.84$; and B: $295.64 \pm 243.81$ compared to before treatment. Testosterone concentration in treatment A: $0.190 \pm 0.063 \mathrm{ng} / \mathrm{ml}$; B: $0.322 \pm 0.210 \mathrm{ng} / \mathrm{ml}$ and C: $1.016 \pm 1.680 \mathrm{ng} / \mathrm{ml})$. It was concluded that giving herbal supplements with formula $\mathrm{C}$ increase libido and the concentration of PO bull testosterone.
\end{abstract}

Key words: Bull, herbal supplementation, libido, testosterone hormone

\begin{abstract}
ABSTRAK
Penelitian ini bertujuan untuk melihat pengaruh pemberian suplementasi herbal terhadap peningkatan libido dan konsentrasi hormon testosteron pada sapi pejantan PO. Penelitian ini dilaksanakan di kandang percobaan, Loka Penelitian Sapi Potong selama 60 hari. Materi penelitian sebanyak 12 ekor sapi jantan PO, masing-masing perlakuan empat ekor dengan kisaran umur 3-5 tahun. Perlakuan yang dilakukan, yaitu perlakuan A (Vitamin A + E + Mineral Zn), B (Vitamin A + E + Mineral Zn +100 gram serbuk daun kelor/ Moringa oleifera), dan C (Vitamin A+ E + Mineral Zn +50 gram serbuk daun kelor/ Moringa oleifera). Analisis data menggunakan Rancangan Acak Lengkap (RAL) dengan One Way Anova. Hasil penelitian menunjukkan bahwa tampilan libido pejantan sapi PO yang diberikan suplementasi herbal menunjukkan nilai yang lebih rendah artinya sapi tersebut memiliki respon yang lebih cepat berturut turut pada perlakuan C : 100,23 $\pm 160,43$; A : 153,83 $\pm 175,84$; dan B: 295,64 $\pm 243,81$ dibandingkan dengan sebelum perlakuan. Konsentrasi hormon testosteron pada perlakuan A : 0,190 $\pm 0,063 \mathrm{ng} / \mathrm{ml} ; \mathrm{B}: 0,322 \pm 0,210 \mathrm{ng} / \mathrm{ml}$ dan C:1,016 $\pm 1,680$ $\mathrm{ng} / \mathrm{ml}$ ). Disimpulkan bahwa pemberian suplemen herbal dengan formula C meningkatkan libido dan konsentrasi hormon testosteron sapi pejantan PO.
\end{abstract}

Kata kunci: Sapi jantan, suplementasi herbal, libido, hormon testosteron 


\section{PENDAHULUAN}

Indikator produktivitas seekor sapi induk salah satunya dilihat dari kemampuan sapi tersebut dalam menghasilkan pedet setiap tahun. Namun demikian kenyataan dilapangan banyak faktor yang menyebabkan kegagalan sapi induk untuk menghasilkan pedet setiap tahun, satu diantaranya adalah faktor pejantan yang bertugas untuk mengawini sapi betina memiliki libido yang rendah. Hal itu berakibat pada rendahnya angka kebuntingan yang berdampak pada panjangnya jarak beranak yang selanjutnya menyebabkan kerugian pada peternak.

Libido atau daya keinginan untuk kawin yang diwujudkan dalam bentuk tingkah laku seksual (sexual behavior), yang terjadi sebagai respon dari ternak jantan karena adanya stimulan (Achmad et al. 2017).

Hormon testosteron adalah hormon yang terlibat dengan sexual desire (libido) yang memberikan stimulus seksual untuk mendorong aktivitas seksual khususnya pada hewan jantan (Rachmadi 2008). Ketersediaan testosteron yang cukup akan menyebabkan peningkatan akumulasi testosteron, akibatnya daerah yang mengaktifkan metabolisme otak dan mengatur libido menjadi aktif (Indrayanto 2011).

Daun kelor atau Moringa oliefera adalah salah satu tanaman herbal, yang mengandung bio-constituents yang memiliki tugas pada aktivitas seksual dan spermatogenesis. Unsur-unsur tersebut antara lain saponin, alkaloid, avonoid, ferulic acid, dan chlorogenic acid (Chauhan et al. 2014). Hasil penelitian Syarifuddin et al. (2017) menunjukkan bahwa pemberian daun kelor kering pada sapi dapat meningkatkan konsentrasi hormon testosteron, libido serta motilitas spermatozoa.

Oleh karena itu, pemberian suplementasi herbal dengan penambahan serbuk daun kelor yang dicampur dengan beberapa bahan lain diharapkan dapat menyelesaikan permasalahan rendahnya libido dan konsentrasi hormon testosteron sapi pejantan PO. Tujuan penelitian ini adalah untuk melihat pengaruh pemberian suplementasi herbal terhadap peningkatan libido dan konsentrasi hormon testosteron pada sapi pejantan PO.

\section{MATERI DAN METODE}

Kegiatan penelitian ini dilaksanakan di kandang percobaan, Loka Penelitian Sapi Potong (Lolitsapi) selama 60 hari. Materi penelitian menggunakan 12 ekor sapi jantan Peranakan Ongole (PO), masing-masing perlakuan sebanyak empat ekor sapi PO jantan dengan kisaran umur 3-5 tahun. Pakan yang dikonsumsi sapi berdasarkan standar pakan pejantan di Lolitsapi; dengan kandungan protein kasar (PK) 12\% dan bahan kering (BK) $3 \%$.

Perlakuan yang dilakukan, yaitu dengan memberikan suplemen herbal plus pada sapi pejantan $\mathrm{PO}$ dengan tiga perlakuan dosis tablet dengan isi kandungan suplemen berbeda, yaitu perlakuan A (Vitamin A + E + Mineral Zn), B (Vitamin A + E + Mineral Zn + 100 gram serbuk daun kelor/ Moringa oleifera L.), dan C (Vitamin A+ E + Mineral Zn + 50 gram serbuk daun kelor/ Moringa oleifera L). Dosis vitamin mengacu pada kebutuhan NRC (2000) per hari/ekor, yaitu vitamin E sebesar 1,62 mg/kg bobot badan (BB) sapi; Vitamin A sebesar 0,064 mg/kg BB sapi, dan mineral Zinc 0,9 mg/kg BB sapi. Parameter yang diamati meliputi respon kecepatan libido dan konsentrasi hormon testosteron.

Cara pengukuran parameter sebagai berikut:

1. Libido dihitung sejak pejantan mendekati pemancing hingga naik (detik).

2. Hormon reproduksi (testosteron) dengan cara pengambilan serum darah pada ternak yang selanjutnya dianalisa dengan metode Radioimmunoassay (RIA) dengan Kit 
Testosteron di Laboratorium Institute of Tropical Disease-Universitas Airlangga, Surabaya.

Analisis data yang diperoleh dianalisis menggunakan Rancangan Acak Lengkap (RAL) dengan One Way Anova menggunakan program SPSS for Windows Version 23 (Sugiyono 2015) dari parameter yang diamati dari tiga perlakuan suplemen herbal yang berbeda.

\section{HASIL DAN PEMBAHASAN}

\section{Libido}

Syarat seekor pejantan untuk menjadi pemacek diantaranya adalah memiliki libido tinggi, kesanggupan melayani/mengawini sapi betina dan kemampuan melayani /mengawini sapi betina. Libido merupakan keinginan kawin yang disebabkan adanya peningkatan hormon testosterone pada sapi jantan (pubertas). Menurut Ratnawati et al. (2015) bahwa libido adalah waktu yang dibutuhkan pejantan untuk mulai mengendus sapi pemancing hingga terjadi ejakulasi. Batasan waktu yang diberikan sekitar 5 menit hingga 10 menit untuk mengetahui kemampuan sapi jantan melakukan ejakulasi. Berikut tampilan libido sapi pejantan PO sebelum dan sesudah pemberian suplemen herbal dengan tiga perlakuan (Tabel 1 dan Gambar 1).

Tabel 1. Libido sapi pejantan PO dengan pemberian suplemen herbal

\begin{tabular}{lccc}
\hline \hline \multirow{2}{*}{ Libido (detik) } & \multicolumn{3}{c}{ Perlakuan } \\
\cline { 2 - 4 } & $\mathrm{A}$ & $\mathrm{B}$ & $\mathrm{C}$ \\
\hline Sebelum & $204,75 \pm 176,46$ & $315,40 \pm 182,10$ & $101,90 \pm 64,77$ \\
Sesudah & $153,83 \pm 175,84^{\mathrm{a}}$ & $295,64 \pm 243,81^{\mathrm{b}}$ & $100,23 \pm 160,43^{\mathrm{a}}$ \\
\hline
\end{tabular}

$\mathrm{A}=$ vitamin + mineral; $\mathrm{B}=\mathrm{A}+$ kelor 100 gram; $\mathrm{C}=\mathrm{A}+$ kelor 50 gram

Superskrip ${ }^{\mathrm{a}, \mathrm{b}}$ pada baris yang sama menunjukkan perbedaan yang nyata $(\mathrm{P}<0,01)$

Berdasarkan hasil analisis statistik pada Tabel 1 menunjukkan bahwa libido pejantan sapi PO setelah diberikan suplemen herbal pada perlakuan A dan $\mathrm{C}$ berbeda nyata $(\mathrm{P}<0,01)$ dibandingkan dengan perlakuan $\mathrm{B}$. Tampilan libido pejantan sapi $\mathrm{PO}$ yang diberikan suplementasi herbal menunjukkan nilai yang lebih rendah artinya sapi tersebut memiliki respon yang lebih cepat berturut - turut pada perlakuan A, B dan C dibandingkan dengan sebelum perlakuan atau kontrol (Gambar 1). Dengan pemberian suplemen herbal yang salah satu bahannya adalah serbuk daun kelor (Moringa oleifera L.) disamping sebagai antioksidan juga mengandung senyawa alkaloid, flavonoid, fenolat, triterpenoida dan tanin (Kumala et al. 2016).

Diduga bahwa pemberian suplemen herbal plus melalui komponen bioaktif yang dimiliki seperti flavonoid, fenol dan fitosterol dapat meningkatkan libido yang berkaitan konsentrasi hormon testosterone dalam plasma darah untuk mendorong sintesis protein pada sel-sel epididymis sehingga dapat memacu proses spermatogenesis dalam tubulus (Campbell et al. 2008; Syarifuddin et al. 2017; Hiola et al. 2010). Mekanisme rangsangan berawal dari stimulus melalui indera penglihatan (visual), penciuman (olfactories) dan perabaan (tactil). Rangsangan dikirimkan ke sistem syaraf pusat, disalurkan melalui sumsum tulang belakang dan sampai pada corpus cavernosus (Luthfi 2015). Pada jaringan erectile ini stimulus dihasilkan neuro transmitter sehingga terjadilah ereksi pada 
penis. Hal ini hampir sama dengan halnya pemberian pada sapi pejantan berupa campuran buah kapulaga dengan telur dan madu (Affandhy et al. 2009) dan pemberian pasak bumi dapat meningkatkan hormon testosteron dan sperma hidup pada kambing (Pratomo \& Yudi 2016).

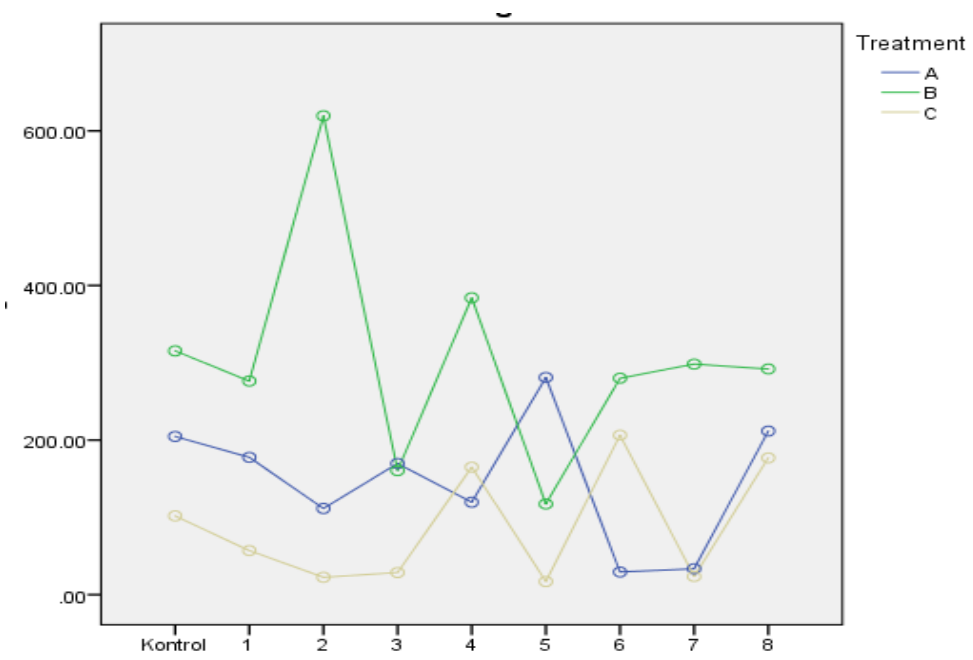

Gambar 1. Grafik libido sapi pejantan PO dengan pemberian suplemen herbal

\section{Hormon testosteron}

Berikut tampilan konsentrasi hormon testosteron sapi pejantan PO sebelum dan sesudah pemberian suplemen herbal dengan tiga perlakuan yang ditampilkan pada Tabel 2.

Tabel 2. Konsentrasi hormon testosteron sapi pejantan PO dengan pemberian suplemen herbal

\begin{tabular}{lccc}
\hline \hline \multirow{2}{*}{$\begin{array}{l}\text { Konsentrasi testosteron } \\
(\mathrm{ng} / \mathrm{mL})\end{array}$} & $\mathrm{A}$ & $\mathrm{3}$ & Perlakuan \\
\cline { 2 - 4 } & $0,272 \pm 0,070$ & $0,147 \pm 0,006$ & $1,075 \pm 1,253$ \\
\hline Sebelum & $0,190 \pm 0,063$ & $0,322 \pm 0,210$ & $1,016 \pm 1,680$ \\
Sesudah & &
\end{tabular}

$\mathrm{A}=$ vit. $\mathrm{A}, \mathrm{E}+$ mineral; $\mathrm{B}=$ vit. $\mathrm{A}, \mathrm{E}+$ serbuk daun kelor 100 gram; $\mathrm{C}=$ vit. $\mathrm{A}, \mathrm{E}+$ serbuk kelor 50 gram

Hasil penelitian menunjukkan bahwa konsentrasi hormon testosteron pada ketiga perlakuan tidak menunjukkan perbedaan pada saat sebelum dan sesudah perlakuan (Tabel 2). Nilai konsentrasi hormon testosteron yang masih rendah karena pengambilannya hanya sekali antara jam 10.00 - 12.00 AM, namun secara deskriptif kita dapat melihat bahwa terjadi peningkatan angka konsentrasi pada perlakuan B. Rendahnya konsentrasi hormon testosteron kemungkinan karena pengambilannya hanya dilakukan sekali pada siang hari, hasil penelitian Rasyid et al. (2003) menjelaskan bahwa konsentrasi hormon testosteron yang paling baik adalah saat pagi hari hingga mencapai $6,1-7,0 \mathrm{ng} / \mathrm{ml}$, sedangkan siang hari $(0-1,9 \mathrm{ng} / \mathrm{ml})$ dan sore hari $(0-4,4 \mathrm{ng} / \mathrm{ml})$ konsentrasinya rendah. Hal ini berarti bahwa penampungan semen pejantan sebaiknya dilakukan pada pagi hari. 
Namun demikian untuk sapi PO dalam kondisi yang memaksa masih memungkinkan untuk ditampung pada sore hari dengan konsentrasi testosteron yang mencapai 4,4 ng/ml. Hal tersebut menunjukkan bahwa pemberian vitamin A, E dan mineral Zn serta serbuk kelor 100 gram/ekor/hari lebih konstan dibandingkan penambahan serbuk kelor sebesar 50 gram/ekor/hari sehingga lebih efektif digunakan untuk memperbaiki fertilitas sapi pejantan sapi potong.

Pengaruh suplemen herbal untuk perbaikan kualitas semen didapatkan dengan melancarkan aliran darah ke organ reproduksi jantan sehingga merangsang efek androgenik, dimana terjadi peningkatan hormon LH yang bekerja pada sel-sel Leydig. Sel-sel Leydig ini mensekresikan testosteron yang dapat mendorong proses spermatogenesis (Affandhy et al. 2017; Campbell et al. 2008), hal yang sama dilaporkan oleh Syarifuddin et al. (2016) menyatakan bahwa suplementasi daun kelor sebesar 15\% dengan pemberian 1\% BB dapat meningkatkan kadar hormone testosterone dalam plasma, libido, dan motilitas sperma pejantan sapi. Dalam mekanismenya, hipotalamus mensekresikan gonadotropin releasing hormone $(\mathrm{GnRH})$ yang akan mensitimulasi hipofesa anterior untuk mensekresikan LH dan FSH, yang akan menstimulasi sel Leydig dan testis mensekresikan testosterone dan esterogen serta sel sertoli mensekresikan inhibin dan aktivin. Testosteron dan estrogen yang dihasilkan oleh sel Leydig bersifat umpan balik negative baik terhadap hipotalamus maupun hipofisa anterior yang akan menekan sekresi GnRH dari hipotalamus dan FSH, serta LH dari hipofisa anterior. Demikian pula inhibin dan aktivin yang dihasilkan oleh sel sertoli bersifat umpan balik negative spesifik terhadap hipofisa anterior (Hasbi \& Gustina 2018). Konsentrasi testosteron serum memiliki pengaruh langsung dalam ekspresi minat seksual pada sapi jantan (Dias et al. 2009) dan permainan rasio testosteron terhadap estradiol peran penting dalam pameran libido (Singh et al. 2009).

\section{KESIMPULAN}

Pemberian suplemen herbal dengan formula C meningkatkan libido dan konsentrasi hormon testosteron sapi pejantan PO.

\section{DAFTAR PUSTAKA}

Achmad FS, Pudjihastuti E, Hendrik MJ, Ngangi L, Raka IGPN. 2017. Penampilan tingkah laku seksual sapi pejantan limousin dan simmental di Balai Inseminasi Buatan Lembang. Jurnal Zootek. 37:276-285.

Affandhy L, Pratiwi WC, Ratnawati D. 2009. Kualitas semen pejantan sapi peranakan. ongole (PO) dengan perlakuan pemberian. suplemen tradisional berbeda. Dalam: Sani Y, Natalia L, Brahmantiyo B, Puastuti W, Sartika T, Nurhayati, Anggraeni A, Matondang RH, Martindah E, Estuningsih SE, penyunting. Prosiding Seminar Nasional Teknologi Peternakan dan Veteriner. Bogor (Indonesia): Pusat Penelitian dan Pengembangan Peternakan. hlm. 173-180.

Affandhy L, Ratnawati D, Luthfi M. 2017. Pengaruh pemberian kombinasi jamu tradisional terhadap kualitas semen dan libido sapi Peranakan Ongole. Trad Med J. 22:84-94.

Campbell NA., Reece JB., Mitchell LG. 2008. Biologi. Jilid ke-3. Edisi ke-8. Lestari R, penerjemah. Jakarta (Indonesia): Erlangga.

Chauhan NS, Sharma V, Dixit VK, Thakur M. 2014. A review on plants used for improvement of sexual performance and virility. BioMed. 19 pages. 
Dias JC, Andrade VJ, Emerick LL, Martins JAM, Filho VR, Silva MA. 2009. Libido test in young guzerat bulls and their associations with reproductive tracts and serum testosterone levels. Arch Vet Sci. 14:204-213.

Hasbi H, Gustina S. 2018. Regulasi androgen dalam spermatogenesis untuk meningkatkan fertilitas ternak jantan. Wartazoa. 28:013-022.

Hiola SF, Adnan, Bahri A. 2010. The fitosterol influence of sea grass (Enhalus acaroides) to mencit fertility (Mus musculus) male. Bionature. 11:1-6.

Indrayanto Y. 2011. Andropause [Tesis]. [Surakarta (Indonesia)]: Universitas Sebelas Maret.

Kumala N, Masfufahtun, Devi DRE. 2016. Potensi esktrak daun kelor (Moringa oleifera) sebagai hepatoprotektor pada tikus putih (Ratus novergicus) yang dinduksi parasetamol dosis toksis. Jurnal Ilmiah Kedokteran. 5:58-66.

Luthfi M. 2015. Respon reproduksi calon pejantan sapi PO yang dipelihara dalam kelompok sex dan model kandang yang berbeda [Tesis]. [Malang, (Indonesia)]: Universitas Brawijaya.

Singh J, Kumar A, Honparkhe M, Dadarwal D, Dhaliwal GS. 2009. Effect of GnRH therapy on Plasma steroids, thyroid hormones and and libido in Breeding Bulls. Ind Vet $\mathrm{J}$. 86:584-585.

Syarifuddina NA, Toleng AL, Rahardja DP, Ismartoyo, Yusuf M. 2017. Improving libido and sperm quality of Bali bulls by supplementation of Moringa oleifera Leaves. Media Peternakan. 40:88-93.

Pratomo H, Yudi. Pemberian pasak bumi mempengaruhi kadar testosteron dan spermatozoa kambing PE. J Kedokteran Hewan. 10:148-152.

Rachmadi A. 2008. Kadar gula darah dan kadar hormon testosteron pada pria penderita diabetes melitus [Tesis]. [Semarang (Indonesia)]: Universitas Diponegoro.

Rasyid A, Affandhy L, Wijono DB. 2003. Profil hormon testosteron dan kualitas semen sapi pejantan peranakan ongole dan silangan simmental. Dalam: Mathius IW, Setiadi B, Sinurat AP, Ashari, Darmono, Wiyono A, Purwadaria T, Murdiati TB, penyunting. Prosiding Seminar Nasional Teknologi Peternakan dan Veteriner. Bogor (Indonesia): Pusat Penelitian dan Pengembangan Peternakan. hlm. 85-90.

Ratnawati D, Widyaningrum Y, Sulistya TA. 2015. Perlakuan exercise pada sapi jantan PO terhadap kualitas peningkatan semen. Dalam: Noor SM, Handiwirawan E, Martindah E, Widiastuti R, Sianturi RSG, Herawati T, Purba M, Anggraeny YN, Batubara A, penyunting. Prosiding Seminar Nasional Teknologi Peternakan dan Veteriner. Bogor (Indonesia): Pusat Penelitian dan Pengembangan Peternakan. hlm. 81-87. 